\title{
TELENOVELA E MUDANÇA SOCIAL NO BRASIL: recepção da representação homossexual $^{1}$
}

\author{
José Aparecido de Oliveira ${ }^{2}$
}

Resumo: Este estudo empírico teve como objetivo avaliar a recepção da representação homossexual da teledramaturgia brasileira, realizada por indivíduos hétero e homossexuais, de modo a compreender qual a contribuição à visibilidade da questão homossexual. A metodologia centra-se nos pressupostos dos Estudos de Recepção para avaliar como os receptores se apropriam do conteúdo da telenovela. Os instrumentos utilizados foram um questionário e uma entrevista semidirigida, aplicados a uma amostra de 402 participantes, jovens hétero e homossexuais, a maioria estudantes de graduação. Os resultados confirmam o potencial político e pedagógico da telenovela em ampliar a discussão sobre a questão homoafetiva; bem como sua capacidade em auxiliar o sujeito homossexual a aceitar sua identidade sexual, bem como encorajá-lo a assumir sua orientação sexual.

Palavras-chave: Telenovela; homossexualidade; estudos de recepção.

\begin{abstract}
This empirical study aimed to evaluate the reception of the homosexual representation of Brazilian teledramaturgy, performed by heterosexual and homosexual individuals, in order to understand the contribution to the visibility of the homosexual question. The methodology focuses on the assumptions of Reception Studies to assess how the receivers appropriate the contents of the soap opera. The instruments used were a questionnaire and a semistructured interview, applied to a sample of 402 participants, young hetero and homosexual, most graduate students. The results confirm the political and pedagogical potential of the soap opera in broad discussion on the homosexual question; and its ability to assist the homossexual to accept his sexual identity, and encourage him to take over their sexual orientation.
\end{abstract}

Keywords: Soap opera; homosexuality; reception studies.

\section{Introdução}

A ficção televisiva no Brasil, desde 1990, reforça paulatinamente a representação de personagens homossexuais. Este não é um movimento isolado, mas integrante de um momento mais amplo que corresponde às lutas por reconhecimento da comunidade homossexual em diferentes instâncias da sociedade. O mesmo ocorre no cinema nacional, na dramaturgia, no lançamento de diversos títulos do mercado editorial. Os meios de comunicação trazem quase diariamente matérias e pesquisas a respeito da homodiversidade, biografias, depoimentos pessoais, justamente em um momento em que mais personalidades

\footnotetext{
${ }^{1}$ Este trabalho resume os resultados empíricos de um estudo mais amplo, que reuniu Análise de Discurso e Estudo de Recepção com 402 participantes jovens em Belo Horizonte. A pesquisa obteve aprovação do Comitê de Ética em Pesquisa e está cadastrada na Plataforma Brasil sob o CAAE: 18001813.3.0000.5508.

${ }^{2}$ Doutor em Ciências da Comunicação pela Universidade Metodista de São Paulo. Docente de Antropologia, Sociologia e Filosofia Centro Universitário Metodista Izabela Hendrix e da Faculdade de Estudos Administrativos de Minas Gerais - FEAD. Líder do Grupo de Pesquisas Specularis - Subjetividades, poder, corpo, consumo e identidade.
} 
começam a tornar pública sua orientação sexual. A despeito de forte reação de setores conservadores, esta visibilidade coincide com certo amadurecimento político da sociedade brasileira e avanço do movimento $\mathrm{LGBT}^{3}$, que capitaliza o engajamento de roteiristas, produtores e atores, dispostos a retratar a homossexualidade ${ }^{4}$ nos produtos culturais mais populares.

A profusão de personagens e temáticas homossexuais produz e amplia a discussão da questão para além do meio acadêmico e dos espaços próprios de lésbicas, gays, bissexuais, travestis e transexuais, chegando aos lares de milhares de brasileiros, permitindo a problematização e discussão da questão. Com a visibilidade da telenovela, é possível perceber a "crescente influência do mercado na produção e difusão de imagens, estilos corporais e atitudes associados às variadas expressões das homossexualidades" (FACCHINI, SIMÕES, 2009, p. 18).

Este papel político da arte é fundamental, pois não só difunde os espaços ocupados pelas minorias, mas também contribui para a efetividade de marcos legais como o reconhecimento da união estável homoafetiva pelo Supremo Tribunal Federal em 2011, referendado pelo Conselho Nacional de Justiça em 2013.

A telenovela, por sua capacidade de informação e discussão, amplia para além dos espaços acadêmicos e jurídicos as questões que ali travadas. Em sociedades conservadoras e com baixo grau de escolaridade, populariza o debate sobre as inovações e avanços que ocorrem primeiro na academia e nos tribunais de justiça. Com algum atraso, se compararmos com nossos vizinhos latino-americanos, as famílias de classe média brasileira e com menor escolaridade se defrontam agora com uma ficção televisiva que desafia a tradicional construção da identidade de gênero e sexualidade veiculada pela família, escola e religião. Novelas argentinas exibem diversas cenas de beijo entre homens desde 2009 (Los Exitosos Pells) e 2010 (Botineras), ambas da Telefe, e em 2013 Farsantes, exibida no canal El Trece.

\footnotetext{
${ }^{3}$ Adotamos neste trabalho a denominação LGBT, aprovada pela Conferência Nacional GLBT, utilizada para referir-se a lésbicas, gays, bissexuais, travestis e transexuais, entendendo que suas recentes variações são abertas e sujeitas a contestações, no que diz respeito ao cuidado de se definir adequadamente o sujeito polítco do movimento. Mesmo com o predomínio desta denominação, é importante frisar que ela pode assumir outras variantes, visando destacar sujeitos políticos de outras identidades (intersexuais), bem como o amplo sentido do "T" (travestis, transexuais e transgêneros) (FACCHINI, SIMÕES, 2009, p. 14-15; FACCHINI, FRANÇA, 2009).

${ }^{4}$ Utilizaremos a categoria homossexualidade, mesmo sendo questionada sua adequação sobre as questões identitárias e políticas dentro do Movimento LGBT. Contudo, preferimos tal designação no lugar da categoria homoafetividade por concordarmos que esta última permita esvaziar o caráter também sexual do sujeito, numa espécie de dessexualidação e afetualização, tal como observa Roberto Efrem Filho (2009, p. 25-26).
} 
No entanto, teóricos ligados à Teoria Queer questionam se se essa visibilidade e debate, sobretudo produzidos a partir da ficção televisiva, permitem maior tolerância e dignidade da condição homossexual, com diminuição do preconceito e violência, ou se apenas reforçam os padrões heteronormativos. ${ }^{5}$ A queixa destes estudiosos está no fato de que boa parte dos personagens homossexuais da telenovela ainda são representados como brancos, ricos, intelectuais, de gosto refinado, o que não corresponde à imensa pluralidade da condição homossexual (COLLING, 2007; MORENO, 1995; PERET, 2005). Todavia, cada vez que a telenovela amplia o número de personagens, bem como discute temas próprios do universo homossexual (homoparentalidade, bissexualidade, etc.), milhares de indivíduos celebram nas redes sociais maior visibilidade de sua questão, o que também pode ser visto em diversos trabalhos acadêmicos que pontuam a capacidade desta mídia em ampliar o debate sobre o heterossexismo.

Ao pesquisador, residente em uma metrópole conservadora, a questão que mais chamou a atenção foi o fato de casais de adolescentes homossexuais trocarem manifestações de afeto nas proximidades de escolas e shopping centers. A despeito das diversas formas de agressão física, verbal e psicológica a que sujeitos homossexuais são vítimas, historicamente obrigados a esconder sua identidade sexual, percebe-se, mesmo em cidades conservadoras, maior ocorrência de homossexuais assumindo publicamente sua orientação sexual, em alguns casos com tímidas manifestações de afeto e carinho em locais públicos, naquilo que alguns chamam de "fim à era da identidade sexual" (WILLIANS, 2009, p. 102).

Demonstrações públicas de afeto entre homossexuais era algo totalmente inusitado há mais ou menos dez anos. Curiosamente, coincidem justamente com o fato de haver maior número de casais homossexuais representados nas telenovelas nos últimos anos, fazendo surgir o problema central desta pesquisa - investigar qual a relação entre a maior visibilidade da representação homossexual nos produtos culturais midiáticos e a postura mais assumida dos sujeitos homossexuais, sobretudo jovens, ao trocarem afetos e manifestarem sua condição homoafetiva. Para tanto, escolhemos a telenovela como produto cultural de maior penetração na sociedade como objeto de estudo, tendo como universo da audiência estudantes de graduação e também sujeitos homossexuais.

\footnotetext{
${ }^{5}$ Expressão utilizada para descrever ou identificar suposta norma social relacionada ao comportamento padronizado heterossexual. O termo deriva, sobretudo do conceito Heterossexualidade Compulsória, usado pela pensadora feminista Adrienne Rich no artigo Compulsory Heterossexuality and Lesbian Experience. No texto a autora é a primeira a discutir a heterossexualidade não como algo natural, mas o resultado de um conjunto de práticas destinados a padronizar a relação sexual e amorosa (RICH, 2010).
} 


\section{Metodologia}

Partindo do atual estado da arte da pesquisa em comunicação e gênero, ainda sem consenso sobre o efetivo papel da teledramaturgia para o tratamento das questões de gênero e sexualidade no Brasil, este estudo teve como objetivo verificar se o aumento da representação homossexual, realizada por indivíduos hétero e homossexuais, contribui de algum modo para a maior visibilidade e discussão das demandas da comunidade homossexual no Brasil. Buscamos também avaliar se essa representação encoraja os sujeitos a aceitar sua orientação sexual, bem como a assumir publicamente sua sexualidade e, desta forma, contribuir para a diminuição do preconceito.

Como boa parte das pesquisas neste campo estão focadas ou nos meios ou na produção (LOPES, 2010, p. 105), elegemos a Teoria da Recepção, com foco no modelo teórico das mediações de Orozco Gómez (2005), para avaliar a recepção/consumo que os indivíduos fazem da representação homossexual na teledramaturgia, bem como o discurso da construção da identidade homossexual destes personagens. Centradas na capacidade de resistência e ressignificação que os receptores fazem dos produtos culturais, as pesquisas de recepção devem ter o cuidado de produzir generalizações a respeito do entendimento que estes receptores possuem destes conteúdos. O alerta é feito por Orozco Gómez (1996, p. 164-165), ao chamar a atenção para o cuidado na relativização dos resultados.

Os instrumentos do Estudo de Recepção consistiram em um questionário de autopreenchimento com 50 questões e uma entrevista semidirigida. Isso nos permitiu conciliar abordagens qualitativas e quantitativas, caracterizando um estudo de desenho transversal. A escolha por um instrumento quantitativo visou obter resultados mais seguros sobre a recepção da telenovela, efetuada tanto por sujeitos hétero quanto homossexuais, dado que esta apropriação não é realizada da mesma maneira, mesmo entre sujeitos pertencentes a uma mesma orientação sexual.

Essa opção comparativa entre o texto televisual da novela e o modo como as audiências se apropriam destes discursos e os ressignificam, além de se constituir em uma ferramenta analítica que possa minimizar possíveis desvios interpretativos e equívocos conclusivos, busca também fugir de alguns consensos das pesquisas em comunicação que partem do pressuposto caráter hegemônico da mídia, visto como unidimensional e relacionado à ideologia dominante (HALL, 2003, p. 368). 
Esta convicção alinha-se à compreensão de que a mídia ocupa posição majoritária no corpo social ao produzir e emitir discursos, visões de mundo e representações sobre a vida social, principalmente sobre as dinâmicas da sexualidade. Mas esta posição, privilegiada e majoritária, não é exclusivamente dominante, uma vez que seus conteúdos repercutem também demandas sociais, políticas e culturais contrárias ao discurso hegemônico (RONSINI, 2012, p. 106), sendo apropriadas e ressignificadas por diferentes sujeitos, ligados a diferentes tradições e injunções institucionais.

\section{Participantes}

O estudo contou com a participação voluntária de 402 participantes, residentes na região metropolitana de Belo Horizonte, MG. Foi realizada uma amostra não probabilística por razões éticas, uma vez que o estudo buscou incluir indivíduos hétero e homossexuais para avaliar como estes realizam o consumo da telenovela. Essa escolha teve por objetivo compreender o modo como a apropriação dos conteúdos culturais ocorre, principalmente em se tratando da homossexualidade, vista como o comportante erótico desviante por boa parte da população, além das próprias disputas e hierarquias adjacentes ao movimento LGBT.

Primeiramente foi realizada uma amostra de conveniência (não intencional) com 281 estudantes de graduação, alunos do pesquisador na instituição de ensino onde foi aplicada à investigação. Nesta primeira etapa de amostragem, percebeu-se que o número de participantes LGBT era muito pequeno para se constituir uma amostragem segura aos objetivos da pesquisa. Seguiu-se então uma segunda amostra (desta vez intencional), que alcançou outros 121 sujeitos homossexuais não estudantes, contatados a partir do apoio dos estudantes homossexuais que participaram da primeira etapa. Essa segunda amostragem teve como objetivo e critério de seleção aumentar o percentual de indivíduos LGBT, permitindo perceber as divergentes apropriações dentro deste universo. Com a percepção das diferentes visões em uma mesma comunidade, ressaltam-se as relações de poder e o caráter excludente que podem estar mascarados em discursos quando categorias são absorvidas.

Desta forma foi alcançada uma população com consideráveis estratos representativos para amparar os resultados deste estudo, conforme as diferentes mediações pelas quais os sujeitos realizam o consumo dos bens culturais (OROZCO GÓMEZ, 2005), fundamental para compreender a percepção da representação dos personagens homossexuais da telenovela, 
efetuada tanto por homens e mulheres, seguidores de religião ou não, hétero ou homossexuais. Essa representatividade demográfica intencional permitiu caracterizar a mediação de referência, que são características culturais próprias da identidade do receptor que incidem no modo como se apropriam dos conteúdos televisivos. Essas referências são idade, gênero, religião, escolaridade, estrato econômico, etnia, origem geográfica e, no caso específico desta pesquisa, identidade sexual. Com essa amostragem obtivemos margem de erro de $5 \%$ e nível de confiança de $95 \%$, conforme população de 7,3 milhões de estudantes do ensino superior (MEC, 2014).

A idade média dos participantes é 24,97 anos $(\mathrm{DP}=7,52)$ e $69,2 \%$ são do sexo feminino. $75,1 \%$ (302) são solteiros, $18,9 \%$ (76) casados e $6 \%$ (24) vivem em união civil homoafetiva. Quanto à identidade sexual agregada, a maioria são heterossexuais $(71,7 \%)$, sendo 55\% mulheres e 16,7\% homens. 114 indivíduos são homossexuais - 28,4\% da amostra. Destes 47 são homens homossexuais (11,7\%), 31 lésbicas (7,7\%), 30 bissexuais (7,5\%), dois transexuais $(0,5 \%)$ e quatro indivíduos indicaram ter outra identidade sexual $(1 \%)$, o que caracteriza o amplo espectro da homossexualidade. Para os efeitos desta amostra, as mediações institucionais que mais interessam ao nosso estudo são família, escola e confissão religiosa, enquanto que as mediações referenciais são gênero e identidade sexual agregada (OROZCO GÓMEZ, 2005).

Figura 1 - Cruzamento de dados / identidade sexual agregada x religião

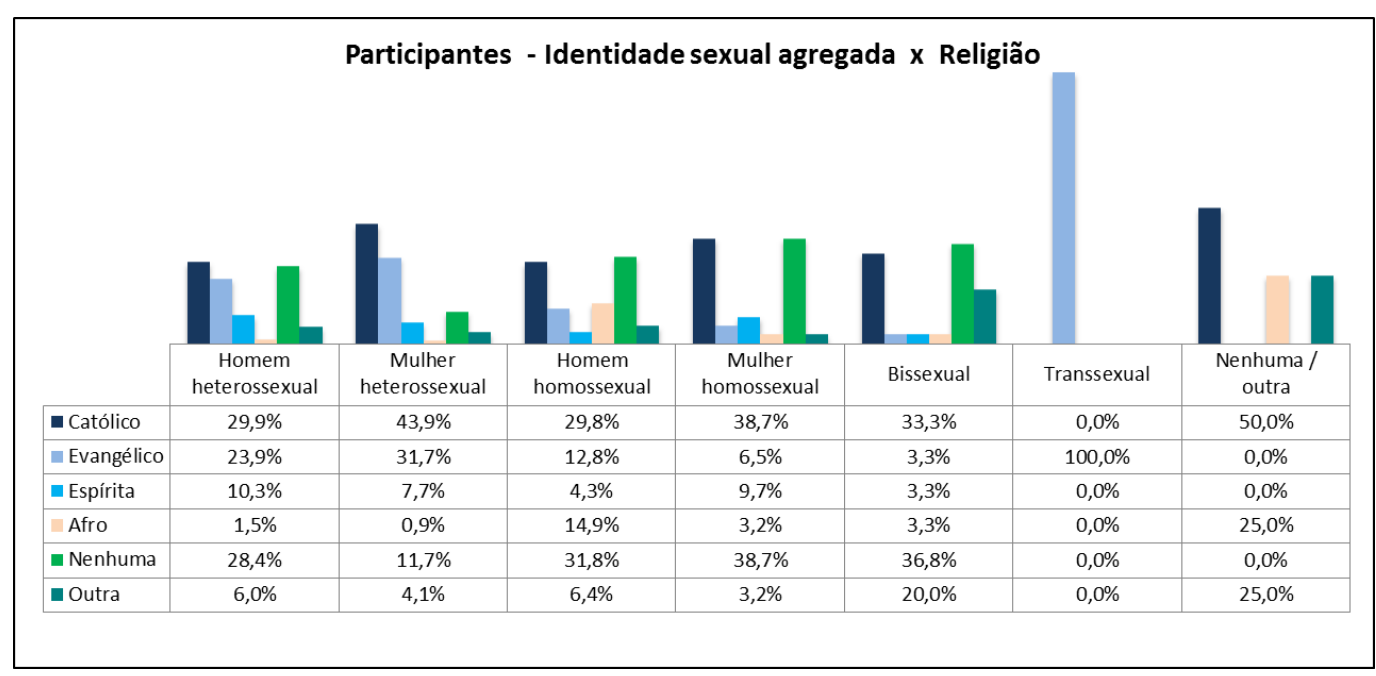




\section{Telenovela e mudanças sociais}

Importante produto da indústria cultural, a telenovela também é vista como meio difusor de práticas urbanistas e sistema de ensino paralelo num país com enorme fragilidade das instituições de ensino (LOPES, 2010, p. 21; 31). Como produto de mercado, a telenovela no Brasil já adotou tom mais nacional do que aquele praticado em seu surgimento e vem abrindo concessões naquilo que alguns autores denominam "cultura da zona sul" (RAMOS, 2012, p. 401). As tramas já não repercutem tão somente os ambientes das elites dos bairros da zona sul carioca (Copacabana, Ipanema, Leblon, etc.) ou os arranha-céus da elite paulistana, mas tem havido crescente espaço para personagens ambientados em espaços como a Baixada Fluminense ou mesmo em comunidades carentes (favelas). Empregadas domésticas, negros, homossexuais, evangélicos, idosos, e outras minorias deixaram de ocupar papéis secundários para tornarem-se protagonistas das novas tramas. A telenovela está se rendendo ao poderoso potencial de consumo da emergente classe $\mathrm{C}$ no Brasil, além da considerável parcela de famílias beneficiadas pelos programas de transferência de renda desde 1995 (MEDEIROS et $a l ., 2007)$.

A telenovela exibe padrões de valores, comportamentos e identidades, influenciando e sendo influenciada - a sociedade naquilo que é tolerado ou até mesmo desejável. É um potente meio de indução ao consumo, oferecendo produtos e serviços em quase todas as esferas de mercado, sobretudo nos nichos de moda, lazer, decoração, automóveis e tecnologia. Embora alguns de seus críticos a denunciem pelo viés de indução ao consumo, a telenovela abriu espaço para a ampliação da discussão de temas sociais que antes circulavam em canais restritos como internet, escola e redes sociais.

Alguns autores começaram a perceber a telenovela em função de seu potencial discursivo para produzir mudanças sociais $^{6}$ (FADUL, 2000, p. 21). Devido à sua forte penetração nos lares, sua trajetória paralela à industrialização e urbanização do país nos últimos anos, suas tramas voltam-se com forte viés para temas e campanhas sociais como adoção, divórcio, alienação parental, terceira idade, pessoas com dependência química, bullyng, síndrome de Down, questões políticas e econômicas, etc., tornando-a um efetivo meio de discussão de temas com apelo social num país ainda com baixos índices de escolaridade.

${ }^{6}$ George Martine pesquisou a contribuição das mensagens subliminares da telenovela para a redução do índice de natalidade no Brasil, bem como a ajudar as pessoas a "separar a sexualidade da procriação" (MARTINE, 1996). 
Comecei a me dar conta que a televisão norte-americana foi o ator que mostrou o divórcio como direito sócio-cultural, mostrou que as mulheres tinham outro estatuto social. E isso jamais havia sido apreendido pela esquerda como uma contribuição para tornar mais livres e laicas nossas sociedades. Assim, quando a constituição colombiana declarou que o país tinha uma sociedade não confessional, que é uma forma indireta de dizer que a sociedade é realmente laica, de separação entre Igreja e Estado, havia muito que agradecer à televisão norte-americana, porque ela, com suas séries, mundializou as pessoas, com os divorciados, os homossexuais, pois criou um ambiente que fez parecer possível e desejável aquilo que a religião havia proibido como antinatural (MARTÍN-BARBERO, 2009, p. 151).

A participação da telenovela no controle da natalidade e no planejamento familiar já foi percebida desde os anos 1960 (FARIA, 1989). Análises de conteúdo demonstraram como as famílias das telenovelas têm sido representadas cada vez com menos filhos ou mesmo sem, o que acompanha, ainda que com alguma assimetria, a realidade das famílias na sociedade (FADUL, 2000, p. 32).

\footnotetext{
Os impactos mais significativos, segundo apontam as pesquisas, referem-se à mudança de comportamento das mulheres, como se pode observar nos índices de natalidade, que aproximam nosso país daqueles mais desenvolvidos. Entretanto, muitas campanhas sociais apresentadas na ficção têm tido profundo impacto na sociedade, como foi o caso das crianças desaparecidas, dos transplantes de medula, da síndrome de Down etc. Acho que a lista é bastante longa e se poderia até mesmo voltar à década de 70 do século passado quando a telenovela Escalada (1975), de Lauro César Muniz, introduziu o problema do divórcio e logo depois essa Lei foi aprovada pelo Congresso brasileiro (FADUL, 2013).
}

A constatação de que a telenovela atua de modo a modernizar as práticas sociais, ligando as conquistas do campo jurídico ao cotidiano das pessoas é percebida também na questão dos direitos dos homossexuais. Mesmo que revisitem "caricaturas e estereótipos, ou ensaiando uma aproximação a imagens mais modernas de gays e lésbicas, travestis ou transexuais" (SIMÕES, FRANÇA, 2005, p. 312), a telenovela se alia a uma série de atores que sinalizam os avanços da comunidade homossexual.

Ao lado do jornal e da internet, esse veículo de comunicação é talvez aquele que tenha a maior capacidade de transmitir ao grande público, sobretudo famílias com baixa escolaridade, as possibilidades que emergem de avanços próprios das instituições acadêmicas e jurídicas. A própria dinâmica de seus códigos de linguagens, acessíveis e atraentes para milhares de pessoas em diversas classes sociais, potencializam a telenovela como um eficiente meio de comunicação para veicular conteúdos, valores e práticas sociais.

Exemplos desta relação entre a telenovela e os avanços no campo do Direito podem ser constatados em recentes produções exibidas no país. A novela Amor e Revolução (2011- 
2012) tornou-se representativa por ser a primeira a ter a ditadura militar brasileira como parte central de seu enredo, além de exibir o primeiro beijo entre duas pessoas do mesmo sexo. ${ }^{7} \mathrm{~A}$ novela abordou também as mudanças comportamentais na década de 1960, como a liberação sexual feminina após a pílula, o feminismo, o movimento hippie, etc. A cena do beijo entre as personagens Marcela (Luciana Vendramini) e Marina (Giselle Tigre) e foi ao ar uma semana após o Supremo Tribunal Federal (STF) aprovar o reconhecimento da união estável homoafetiva.

Outro exemplo é a questão da união civil homoafetiva, também retratada na novela $E m$ Família. O casal formado por Clara (Giovanna Antonelli) e Marina (Tainá Müller) se uniram após Clara se separar do marido Cadu (Reynaldo Gianecchini) e assumir sua relação lésbica. Além de exibir um beijo entre as duas, a trama retratou o casamento no dia 16/07/2014, numa clara referência à união civil homoafetiva consolidada pelo Conselho Nacional de Justiça em 2013, que exigiu que os cartórios atendessem a resolução do Supremo Tribunal Federal de 2011. Muitos cartórios se recusavam a registrar os pedidos de casamento entre homossexuais. Todavia, não é o mesmo entendimento de alguns intelectuais ligados à Teoria Queer, dentre eles Butler (2003) e Miskolci (2007). Para tais estudiosos, buscar o casamento de pessoas do mesmo sexo e também a possibilidade de adotar filhos é o mesmo que enquadrar sujeitos homossexuais ao padrão heteronormativo.

\begin{abstract}
A petição por direito ao casamento procura o reconhecimento do Estado das relações não-heterossexuais e, assim, deveria conceder de maneira não discriminatória, independente de orientação sexual. Essa concessão do Estado intensifica a normalização, que parece passar desapercebida por boa parte do movimento lésbico e gay organizado (BUTLER, 2003, p. 224).
\end{abstract}

O mesmo se pode dizer das experiências em outros países em que a telenovela ajudou a transformar valores e práticas próprias de sociedades tradicionais. Uma experiência mais recente dá conta do uso de vários programas de entretenimento-educação focados na radionovela para ajudar a combater as práticas de mutilação genital feminina, o alto índice de natalidade e a expansão da AIDS, em especial em países de forte tradição islâmica como o Sudão.

\footnotetext{
${ }^{7}$ Um dos primeiros beijos representado por personagens homossexuais teria ocorrido em 1990 na minissérie Mãe de Santo, exibida pela extinta TV Manchete. Protagonizada pelos atores Raí Bastos e Daniel Barcelos, a cena, no entanto, foi realizada à contra luz, o que não permite concluir se houve realmente o beijo, apenas sua sugestão (OLIVEIRA, 2011). Todavia, na década de 1960, Vida Alves trocou o primeiro beijo com Geórgia Gomide em um teleteatro na extinta TV Tupi.
} 
Pensativo e visivelmente reflexivo, Ali, que era um ouvinte ávido de Ashreat Al Amal (Sails of Hope), uma radionovela de entretenimento-educação, lutava sobre como ele poderia transmitir em um desenho os significados pessoais derivados do ouvir seu programa de rádio favorito. Cerca de 20 minutos depois, segurando o desenho colorido na mão, ele murmurou: "Com uma antena nós podemos parar com a prática da mutilação genital feminina" (GREINER et al., 2007, p. 228).

\section{Telenovela e preconceito: análise e discussão dos resultados}

Para os limites deste artigo, será focado o terceiro bloco do questionário, que compreende 20 questões, destinadas a avaliar a representação dos personagens homossexuais e a percepção dos receptores sobre uma provável influência da telenovela em questões como preconceito, aceitação e discussão da homossexualidade, seguidas da exposição de trechos da entrevista semidirigida.

Quatro questões procuraram verificar se os participantes percebem a mudança no padrão de representação dos personagens homossexuais na telenovela, sobretudo nas características de seu comportamento. $62 \%$ discordaram quando perguntados se os personagens homossexuais são representados de forma debochada, explícita ou agressiva. Os homossexuais também não são mais representados como pessoas perigosas e sedutoras, conforme $67,1 \%$ dos participantes, tampouco como pessoas criminosas e violentas $(80,1 \%)$. Os participantes também discordam quando perguntados se os personagens homossexuais são representados como pessoas preconceituosas, conforme 62,2\% dos entrevistados. Para 57,9\% os personagens homossexuais são representados como pessoas de boa índole (honestas, cultas, corretas).

\footnotetext{
Não condiz com a verdade, com os gays pobres, pretos, espalhafatoso. Mas eu acho que é pra mostrar que não porque ele é gay que ele tem que ser inferior, ele é médico, é advogado, pode ser o que for, pode ser pai, só porque é gay vai ter que se prostituir? Não, ele pode estudar, pode trabalhar, pode ter uma carreira. etno 04 receptor $\mathrm{A}$
}

Como se percebe no comentário da entrevista semidirigida acima, os participantes ressaltam o padrão refinado da representação dos personagens homossexuais, distante da grande maioria destes sujeitos, embora reconheça a intencionalidade da emissora em diminuir o estereótipo contra os homossexuais. Com isso, temos a mediação videotecnológica de Orozco Gómez (2005), que vê a TV como meio técnico de produção e transmissão de informação, mas também um meio que produz significados conforme uma agenda política, 
econômica e cultural, capaz de produzir reações na audiência e naturalizar o discurso do acontecimento social reproduzido, tornando-o verossímil. Embora esta representação dos personagens homossexuais ainda siga o padrão heteronormativo (COLLING, 2007), não há dúvidas da estratégia comercial da emissora, interessada em não aumentar a resistência aos personagens homossexuais e ampliar sua fatia no mercado. Percebe-se também que a telenovela busca diminuir o estereótipo recorrente associado à imagem do homossexual, tido por alguns como espécie de aberração, pedófilo, promíscuo, sedutor, etc. A representação positiva da telenovela é parte de sua estratégia em atrair a simpatia do público pelo indivíduo homossexual, alinhada com o Mercado GLS (gays, lésbicas e simpatizantes), contribuindo não apenas para a ideia de "orgulho gay”, mas também como uma própria delimitação da ação política (e também econômica, mercadológica) dos empresários (FACCHINI, FRANÇA, 2009).

Se compararmos esse padrão de representação da telenovela com o padrão de representação do homossexual da maior parte do cinema brasileiro de alguns anos atrás, ${ }^{8}$ ao menos percebemos como a telenovela pode contribuir para a maior aceitação do indivíduo homossexual, gerando empatia e solidariedade do público para com os personagens e sujeitos homossexuais. Só mais recentemente é que o cinema nacional adotou representação mais favorável e humanizada da condição homossexual, embora esta temática ocorra em muito pouco dos filmes lançados, se comparados com a novela.

[...] as qualidades atribuídas às personagens homossexuais nos filmes brasileiros analisados, o retrato social do homossexual, em forma condensada, seria a de um sujeito alienado politicamente; existente em todas as classes sociais, com preponderância na classe media baixa, onde, geralmente, tem um subemprego; de comportamento agressivo e que usa, frequentemente, um gestual feminino exacerbado, o que se estende ao gosto pelo vestuário; e que, nos relacionamentos interpessoais, mostra tendência à solidão e é incapaz de uma relação monogâmica pois utiliza-se de vários parceiros, geralmente pagos, para ter companhia (MORENO, 1995, p. 136).

Três questões buscaram avaliar a estratégia dos roteiros em apresentar os personagens homossexuais como pessoas comuns, dotadas de sensibilidade e afeto, o que os credencia à exigência dos mesmos direitos que os demais indivíduos da sociedade. Para $57,4 \%$ dos participantes, a forma como os personagens homossexuais são representados permite

\footnotetext{
${ }^{8}$ Moreno analisou 125 títulos do cinema nacional onde aparecem personagens homossexuais. Até aquela época poucos títulos apresentaram o homossexual de forma mais humanizada e longe do estereótipo negativo (MORENO, 1995).
} 
identificá-los como pessoas capazes de educar uma criança. 88,3\% dos participantes concordam que os homossexuais são representados de forma a serem vistos como pessoas capazes de amar alguém. Percentual semelhante $(89,1 \%)$ também concordou quando perguntados se os homossexuais são representados de maneira a vê-los como pessoas dotadas de sensibilidade.

$80,6 \%$ dos participantes concordaram que o padrão de representação dos homossexuais permite vê-los como sujeitos de direitos e deveres. Perguntados se os homossexuais na telenovela são representados como pessoas que merecem respeito e tolerância, 84,4\% dos participantes concordaram com a questão. De igual modo, 72,1\% concordaram com a representação dos homossexuais como pessoas merecedoras da simpatia da sociedade. No entanto, $41,3 \%$ dos participantes se revelaram indecisos quando questionados se a representação dos homossexuais permite identificá-los como pessoas exigentes e politizadas.

Tais dados parecem indicar o tom cauteloso com que a teledramaturgia trabalha a questão da homossexualidade, explicada pelas pesquisas de opinião da Rede Globo e alguns cortes em cenas, em função do temor da perda da audiência e de anunciantes. Embora aumente o número de personagens homossexuais, com discurso e gestual mais característico dos indivíduos LGBT, a estratégia parece suavizar os apelos políticos que permeiam setores do Movimento LGBT. Na novela Império (2014), a emissora chegou a cortar três cenas de beijo entre personagens homossexuais, o mesmo ocorreu com a novela Babilônia (2015), em que cenas de beijo, gravadas entre as atrizes Fernanda Montenegro e Nathalia Timberg, foram cortadas para tentar reverter o boicote de segmentos conservadores à novela.

[...] é complicado quando você fala se está sendo bom ou não, por exemplo, aquele casal, são homens muito bonitos, bem sucedidos, então, eles forçam a imagem do que é um homem padrão, mas não mostram hoje um gay que é negro, que não é feliz, que não tem um relacionamento ótimo, porque ele não vai ter hoje a aceitação por exemplo, a novela não vai mostrar assim. Concordo sim, que os casais representados não representam a totalidade do homoafetivo, porém, não se pode negar que é uma ótima tentativa de introduzir uma discussão. etno 01 - receptor $\mathbf{H}$

Os participantes ressaltam o padrão refinado dos personagens homossexuais, embora reconheçam a intencionalidade em diminuir o estereótipo contra os homossexuais. Mesmo que esta representação dos personagens homossexuais siga ainda o padrão heteronormativo (COLLING, 2007), não há dúvidas do reforço autoral e das recorrências estilísticas dos 
profissionais engajados. Atores, produtores, roteiristas, etc., alguns por questões identitárias utilizam seu trabalho para pontuar a presença e visibilidade LGBT nos produtos culturais.

Quatro questões (Q17 - Q20) buscaram avaliar o potencial da telenovela em ampliar a discussão sobre a questão homoafetiva, se ela encoraja o sujeito homossexual a aceitar sua identidade sexual; bem como a assumir publicamente sua orientação sexual. Questionados se a representação dos homossexuais na telenovela permite-lhes repensar a condição de quem possui orientação sexual diferente (Q18), 56,7\% concordaram com a questão, contra 17,4\% que discordaram e $25,9 \%$ indecisos. No cruzamento desta questão com a variável 'identidade sexual agregada', os indivíduos heterossexuais e homossexuais percebem de forma quase semelhante o impacto da telenovela em produzir a reflexão sobre a condição homossexual. Dentre os participantes heterossexuais, destaque para $62,8 \%$ das mulheres e $46,3 \%$ dos homens, concordes com a questão. Entre os homossexuais, 55,3\% dos gays e $45,1 \%$ das lésbicas, seguidos de 53,3\% dos bissexuais, acompanharam raciocínio favorável. Já no cruzamento da Q18 com a variável religião, católicos e espíritas são os que mais se mostram alinhados com essa perspectiva. 68,4\% dos católicos e 73,3\% dos espíritas concordam que a telenovela leva-os a repensar a condição homossexual. Participantes evangélicos, afrodescendentes e sem religião são favoráveis à questão, mas em menor grau (com 48,8\%, $38,4 \%$ e $42,2 \%$, respectivamente).

\footnotetext{
Eu acho que ajuda que ajuda sim a diminuir o preconceito, porque o homossexual já tem o preconceito dentro de casa, você passa a conhecer um pouco mais sobre a vida de cada um, principalmente os pais de homossexuais. A gente passa a conhecer seus gostos, vontades, isso ajuda a abrir a cabeça das pessoas... Saber entender o que eles passam, o sentimento deles, eles são afastados, criticados. A gente vendo essa cena se comove... comove, isso ajuda a mudar a gente... etno 07 - receptor $\mathbf{A}$
}

Estes dados parecem confirmar o papel da telenovela em ampliar o debate sobre a questão homossexual, reforçando o que alguns teóricos já demonstravam sobre seu potencial pedagógico (FADUL, 2013; GREINER et al., 2007; RINCÓN, 2011). Todavia, a adesão menor dos participantes evangélicos demonstra como espaços tradicionais de mediação cultural como família e confissão religiosa incidem diretamente na forma como os conteúdos simbólicos da ficção televisiva são apropriados. Isso alerta para os limites da intencionalidade da ficção televisiva, pois relativiza a suposta hegemonia dos meios de comunicação em produzir e veicular conteúdos simbólicos. 
Acho também que as pessoas abrem a cabeça. Se for parar pra pensar tantas coisas que antigamente eram vistas como absurdas aos poucos foram se tornando normal. Com a homossexualidade vai se tornar a mesma coisa. E pra acontecer tem que ser desta forma. etno 07 - receptor $\mathbf{B}$

Procurando saber qual a contribuição da telenovela para os indivíduos homossexuais aceitaram sua condição, $63 \%$ dos participantes acreditam que a representação homoafetiva na telenovela contribui para o indivíduo aceitar sua orientação sexual (Q19). Apenas 10,7\% discordam da afirmação e 26,4\% mostram-se indecisos. Os dados, quando cruzados com a variável 'identidade sexual agregada', evidenciam que os participantes heterossexuais estão ligeiramente mais alinhados com a questão (59,7\% dos homens e 69,3\% das mulheres). Entre os participantes homossexuais, o percentual de concordância é menor, oscilando entre 50 a $54,9 \%$, com considerável percentual de indecisos entre os 36 participantes bissexuais e transexuais (40 a 50\%). Para estes últimos, a contribuição da telenovela não é tão percebida por não haver, ainda, personagens conforme a ampla dimensão da condição homossexual.

Eu preferi falar para minha mãe que era homossexual. Mas foi depois que eu me aceitei como homossexual. Demorou muito que eu me assumisse, mas isso ajudou muito que eu pudesse falar para minha mãe. Ela aceitou, entendeu, mas meu pai não. Depende muito da família que você tem... Eu fui abusado pelos meus irmãos mais velhos... Passei anos fazendo psicoterapia, mas eu consegui me aceitar, aí sim eu falei para ele. Hoje em dia meu pai não aceita nem a pau o fato de eu ser gay. Os meus irmãos continuam não aceitando, problema deles. etno 03 - receptor B

Figura 2 - Cruzamento Q19 (encoraja o homossexual a aceitar sua orientação sexual) versus Religião.

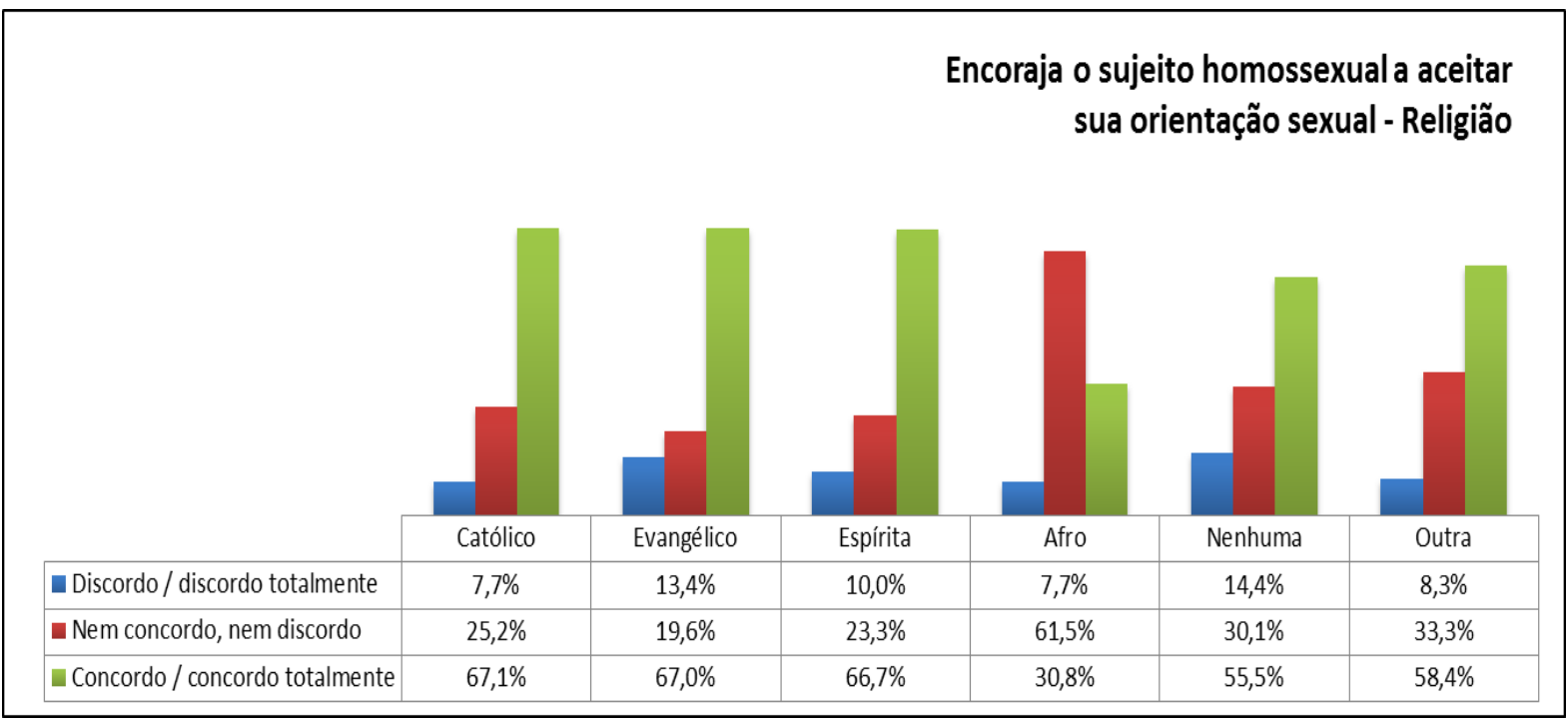


Perguntados se a telenovela encoraja o homossexual a assumir publicamente sua orientação (Q20), 57,3\% concordam com a questão. O percentual de indecisos chegou a $29,6 \%$ e os contrários somam 13,2\%. Entre os participantes heterossexuais, $65,2 \%$ das mulheres e 53,7\% dos homens veem a telenovela como fator de encorajamento da autoafirmação homossexual. Este percentual de confiança novamente é ligeiramente menor entre os participantes homossexuais (46,8\% dos gays; $45,1 \%$ das lésbicas; $40 \%$ dos bissexuais e 50\% dos transexuais). Entre os que discordam, gays e lésbicas são os mais representativos (23,4\% e $29,1 \%$, respectivamente), enquanto que a indecisão se acentua mais entre bissexuais $(43,3 \%)$ e transexuais $(50 \%)$ (FIGURA 2).

Figura 3 - Cruzamento Q20 (encoraja o sujeito homossexual a assumir publicamente sua orientação sexual) versus Identidade sexual agregada.

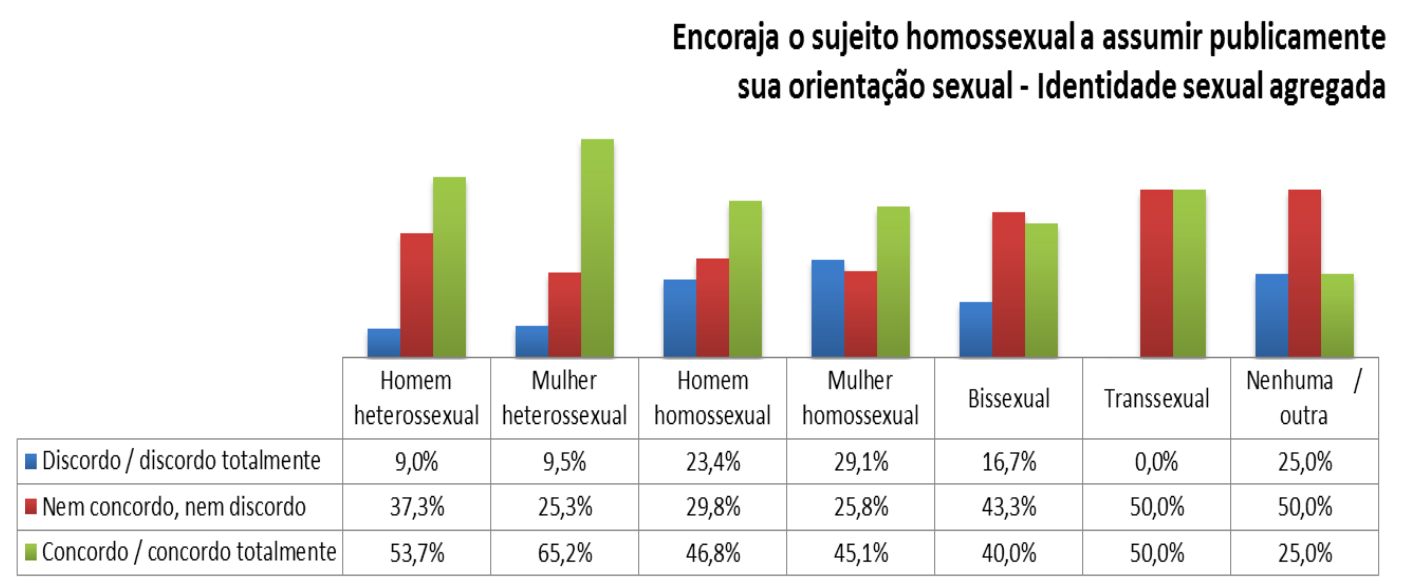

No cruzamento com a variável 'religião', desta vez os evangélicos $(69,1 \%)$ são os que se mostram mais alinhados com a autoafirmação homossexual a partir do consumo da telenovela, seguida de 57,4\% dos católicos, 60\% dos espíritas, 30\% dos afrodescendentes e 50,6\% dos sem religião. A concordância dos evangélicos explica as reações contra cenas de afeto entre personagens homossexuais na telenovela. Esses setores conservadores sabem do papel da construção de gênero e do heterossexismo trabalhado nas instâncias da família, escola e igreja. A telenovela atua como uma instância poderosa para contrapor a este heterossexismo.

Esses números, animadores com relação ao potencial de ampliação do debate da telenovela e suas possibilidades para fazer frente à construção social de gênero e sexualidade, ainda não nos permitem perceber, ao menos no presente, a eficácia deste produto cultural para 
diminuir a homofobia. Quando perguntados se a representação dos personagens homossexuais permite concluir que a novela diminui o preconceito (Q17), o percentual de indecisão mostrase considerável entre os participantes (FIGURA 3).

Figura 4 - Cruzamento Q17 (permite-me concluir que a novela diminui o preconceito) versus Identidade sexual agregada

Permite-me concluir que a novela

diminui o preconceito - Identidade sexual agregada

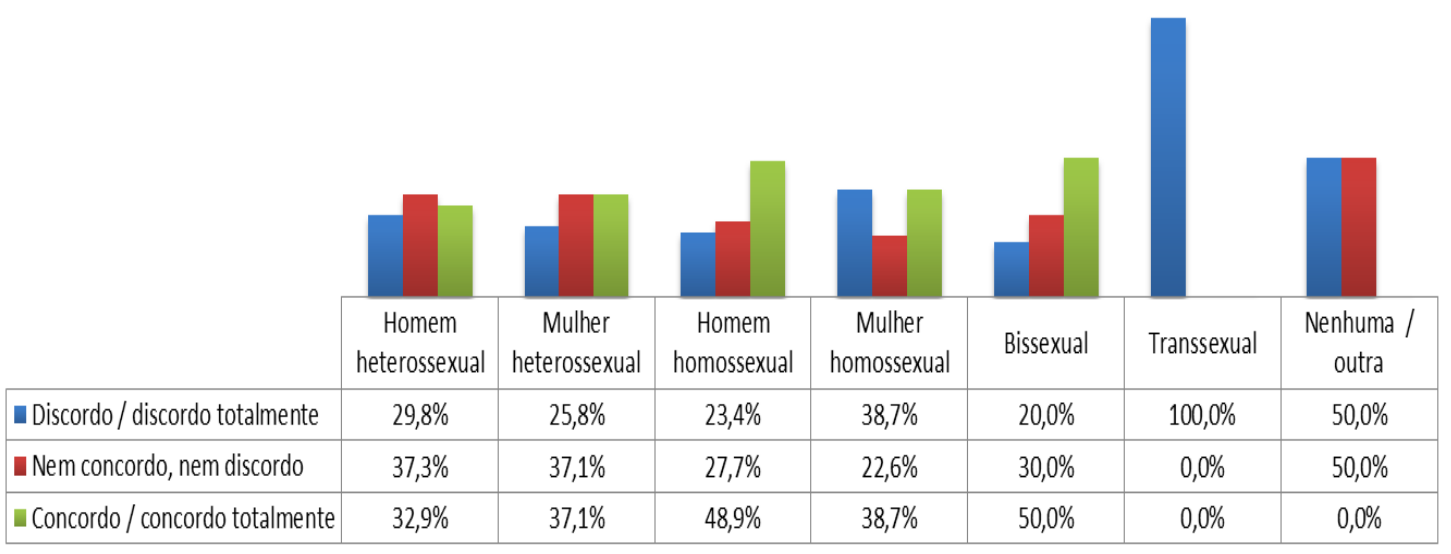

Dos 402 participantes, 38,3\% disseram concordar com a eficácia da representação homoafetiva na telenovela para diminuir o preconceito. $34,3 \%$ dos participantes mostraram-se indecisos (nem concordo e nem discordo), ao passo que 27,4\% disseram não concordar com a afirmação. Os participantes homossexuais são ligeiramente mais favoráveis à questão $(58,9 \%$ dos gays e 38,7\% das lésbicas contra 32,9\% dos homens e 37,1\% das mulheres homossexuais). Os espíritas são mais favoráveis (53,\%, contra 41,9\% dos católicos e 31,9\% dos evangélicos). Com a indecisão, ainda não é possível afirmar que a representação da diversidade homossexual da telenovela contribui efetivamente para romper tabus e preconceitos historicamente construídos numa sociedade conservadora.

Eu acho positivo a telenovela fazer com que demonstre a relação de duas pessoas. Mesmo que mostre um cara bem sucedido, são dois cidadãos, duas pessoas de bem, contrário ao estereótipo comum que vê os gays como bichinhas. É uma forma de fazer a mãe de um homossexual aceitar com mais facilidade o que o filho dela está passando. Eu acho que contribui sim. etno 02 - receptor D 
Apesar da indecisão quanto à questão da diminuição do preconceito, os homossexuais são mais aptos a ver a telenovela como aliada na luta contra o preconceito (48,9\% dos gays; $38,7 \%$ das lésbicas e $50 \%$ dos bissexuais concordam). A indecisão é mais percebida entre os heterossexuais (37,3\% dos homens e 37,1 das mulheres). Entre os que discordam, a maioria é de lésbicas (38,7\% contra $23,4 \%$ dos gays), seguida dos participantes transexuais e sem identidade sexual definida. A discordância aparentemente se explica pelo enorme grau de invisibilidade das lésbicas e dos sujeitos transexuais, vítimas de preconceito dentro da própria comunidade LGBT. Já no cruzamento da (Q17) com a variável ‘religião’ (FIGURA 4), dentre os que concordam com o potencial da telenovela em diminuir o preconceito, a maioria são espíritas $(53,3 \%)$, seguida dos católicos $(41,9 \%)$ e de matriz afro $(38,4 \%)$. Os indecisos também estão mais entre os de matriz afro $(46,2 \%)$, seguidos dos evangélicos $(40,3 \%)$. O maior percentual dos que discordam da afirmação está entre os que declararam seguir nenhuma religião $(39,8 \%)$.

Figura 5 - Cruzamento Q17 (permite-me concluir que a novela diminui o preconceito) versus Religião

\section{Permite-me concluir que a novela \\ diminui o preconceito - Religião}

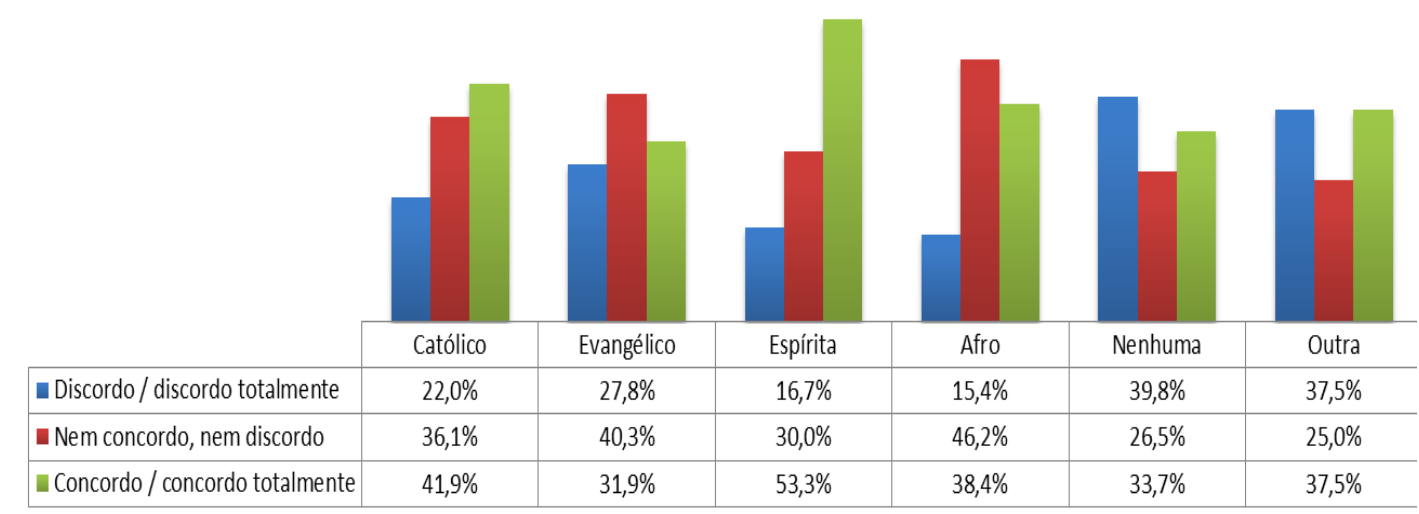

\section{Considerações finais}

Uma vez que são os homossexuais (45,8\% dos 114 participantes gays) que se mostram mais aptos a enxergar a telenovela como aliada na luta contra a homofobia e, dentre estes, a maioria são católicos e os que não seguem religião, temos a confirmação de uma importante hipótese deste estudo: a telenovela, como produto cultural hegemônico, produz novas 
representações que podem ser apropriadas e transformadas em um significativo espaço para canalizar aspirações e demandas por reconhecimento e aceitação da comunidade homossexual.

Embora alguns pesquisadores não sejam propensos a ver a telenovela como coadjuvante nas demandas por reconhecimento da comunidade LGBT, é cada vez mais crescente em blogs e nas redes sociais comunidades e indivíduos que celebram a performance da representação de personagens homossexuais, sobretudo quando temas como homoparentalidade, bissexualidade, transexualidade, etc., são abordados em novelas e seriados. Fortalecidos pelo crescente tratamento de sua questão, estes indivíduos experimentam, ao menos na dimensão virtual e tecnológica, as possibilidades de encorajamento para fazer frente ao fenômeno da construção social de gênero e identidade sexual promovida pelas instâncias da família, escola e religião na sociedade. A telenovela, por seu caráter folhetinesco, foge um pouco ao padrão de

histórias pessimistas, de amores impossíveis que terminam de forma trágica, refletindo assim as autoras sobre a impossibilidade de levar normalmente uma relação lésbica (SIMONIS, 2007, p. 107-140).

Os homossexuais celebram o posicionamento político-ideológico de sua maior representação na ficção televisiva, pois uma parcela importante da comunidade artística, cujos integrantes estão ligados por questões identitárias, produz cada vez mais personagens e temáticas ligadas ao universo LGBT. A partir dos resultados desta pesquisa, estamos propensos a enxergar certo viés de diminuição lenta e crescente no preconceito contra homossexuais a partir do crescente padrão de representação da identidade homossexual na ficção televisiva, mesmo com as reações conservadoras. Percebemos, diferentemente de Colling (2007), que a recente representação homossexual na telenovela não atua de forma a reduplicar os preconceitos contra os homossexuais.

A telenovela não é única nesse aspecto da luta por emancipação e tolerância. Crescem no mercado editorial publicações de viés homoerótico, bem como se multiplicam roteiros e produções teatrais, filmes que versam sobre o tema, fugindo dos tradicionais enfoques caricatural e marginal da condição homossexual. São crescentes no meio acadêmico as pesquisas, seguidas das iniciativas no campo das políticas públicas que visam uma educação contra a homofobia. O judiciário, em vários países, antecipa todo esse espírito e legaliza a homoconjugalidade, permitindo que os indivíduos homossexuais desfrutem dos mesmos 
direitos que os demais cidadãos. Mas são os produtos culturais populares como a telenovela que irão ampliar e popularizar o debate, auxiliando a formar gerações mais tolerantes e aptas a aceitar e oferecer espaço aos homossexuais. É nessa perspectiva que apoiamos a noção de que a multiplicação dos discursos engendra, posiciona, marginaliza mas, em outro sentido, abre também portas para construir possibilidades, sobretudo a partir da literatura e posteriormente da mídia, de aceitação da condição homossexual.

\begin{abstract}
Não somente assistimos a uma explosão visível de sexualidades heréticas, mas, sobretudo - e esse é o ponto mais importante - a um dispositivo bem diferente da lei: mesmo que ele se apoie localmente em procedimentos de interdição, ele assegura, através de uma rede de mecanismos entrecruzados, a proliferação de prazeres específicos a multiplicação de sexualidades disparatadas (FOUCAULT, 1988. P. 48).
\end{abstract}

Mesmo com as reações e a constante violência a que os sujeitos LGBT ainda estão expostos diariamente no Brasil, faz-se necessário destacar a recente mudança no padrão de representação da telenovela no que diz respeito à homossexualidade. Principalmente se percebermos que manifestações de afeto como o beijo e maior tratamento da questão começaram a ocorrer após 2010, e seus efeitos só agora se reproduzem em outros conteúdos da teledramaturgia. Acreditamos, tal como relatado por alguns participantes da entrevista semidirigida, que a maior aceitação da condição homossexual e a consequente diminuição do preconceito contra homossexuais virá paulatinamente, tal como ocorreu com a questão do divórcio quando representado na teledramaturgia. Os resultados também confirmam a perspectiva de Orozco Gómez (2005), que vê a mediação televisiva como um complexo jogo dentro de uma economia de significados. Apesar de a televisão seguir lógica própria para produzir significados em suas audiências, as leituras são plurais conforme as diferentes mediações a que os receptores estão ligados.

\title{
Referências
}

BUTLER, Judith (2003). O parentesco é sempre tido como heterossexual?. Cad. Pagu, Campinas, $\quad$ n. 21, 2003. $\quad$ Disponível em <http://www.scielo.br/scielo.php?script=sci_arttext\&pid=S010483332003000200010\&lng=en\&nrm=iso>. Acesso em 08 Jul 2014 . http://dx.doi.org/10.1590/S0104-83332003000200010.

COLLING, Leandro (2007). Personagens homossexuais nas telenovelas da Rede Globo: criminosos, afetados e heterossexualizados. Revista Gênero, volume 8, número 1, 2007. 
Disponível em <http://www.ieg.ufsc.br/admin/downloads/artigos/01022011-01492314collingleandro.pdf> Acesso em 24 jan 2012.

FACCHINI, Regina; SIMÕES, Júlio Assis. (2009). Na trilha do arco-íris. Do movimento homossexual ao LGBT. São Paulo: Fundação Editora Perseu Abramo. (Coleção História d o Povo Brasileiro).

FACCHINI, Regina, Isadora Lins FRANÇA. (2009). De cores e matizes: sujeitos, conexões e desafios no Movimento LGBT brasileiro. Sexualidad, Salud y Sociedad. No 3, 2009, p.p. 5481 .

FARIA, Vilmar (1989). Políticas de governo e regulação da fecundidade: consequências não antecipadas e efeitos perversos. Ciências Sociais Hoje. São Paulo: Vértice, p.62-103.

FADUL, Anamaria (2000). Telenovela e família no Brasil. Comunicação \& Sociedade, vol. 22, n.34, p.13-39. Disponível em <https://www.metodista.br/revistas/revistasims/index.php/CSO/article/view/4315/3973> Acesso em 14 jun 2012.

. (2013). "Não se pode criticar a telenovela por preencher uma lacuna". Entrevista a Diego Moura. Observatório da Imprensa. Edição 736, 05 mar. Disponível em:

<http://www.observatoriodaimprensa.com.br/news/view/_ed736_nao_se_pode_criticar_a_tele novela_por_preencher_uma_lacuna>. Acesso em: 20 jul. 2013.

EFREM FILHO, Roberto (2014). Os ciúmes do Direito. O desejo pelas uniões homoafetivas e a repulsa a Amor Divino e Paixão Luz. Sexualidad, Salud y Sociedad. No 16, abr. pp.10-30.

Disponível em: <http://www.scielo.br/scielo.php?script=sci_arttext\&pid=S1984-

64872014000100002\&lng=en\&nrm=iso>. http://dx.doi.org/10.1590/S1984-

64872014000100002. Acesso em: $20 \mathrm{dez} 2016$.

FOULCALT, Michel (1988). História da sexualidade I: a vontade de saber. Tradução de Maria Thereza da Costa Albuquerque e J. A. Guilhon Albuquerque. Rio de Janeiro: Edições Graal.

GREINER, Karen; SINGHAL, Arvind; HURLBURT; Sarah (2007). "With an antenna we can stop the practice of female genital cutting": a participatory assessment of Ashreat Al Amal, an entertainment-education radio soap opera in Sudan. In Investigación y Desarrollo. ISSN 0121-3261, Vol. 15, Nº 2, pp. 226-259. Disponível em $<$ http://rcientificas.uninorte.edu.co/index.php/investigacion/article/view/856/501> Acesso em 20/10/2013.

HALL, Stuart (2003). Reflexões sobre o modelo de codificação/decodificação. Uma entrevista com Stuart Hall. In SOVIK, Liv. (Org.) Da diáspora: identidades e mediações culturais. Belo Horizonte: Ed. UFMG; Brasília: Unesco.

LOPES, Maria Immacolata Vassallo de (2010). Pesquisa em comunicação. São Paulo: Loyola. 
MARTÍN-BARBERO, Jésus (2009). Uma aventura epistemológica. Entrevista a Maria Immacolata Vassallo de Lopes. Matrizes, v.2, n.2, p.143-162. Disponível em: <http://www.matrizes.usp.br/index.php/matrizes/article/view/111/178>. Acesso em: 20 out. 2012.

MARTINE G. (1996). Brazil's fertility decline, 1965-95: a fresh look at key factors. Population and Development Review; 22: 47-75.

MEDEIROS, Marcelo; BRITTO, Tatiana; SOARES, Fábio (2007). Transferência de renda no Brasil. Novos estudos - CEBRAP, n.79, p.5-21, nov.. Disponível em: $<$ http://www.scielo.br/scielo.php?script=sci_arttext\&pid=S010133002007000300001\&lng=en\&nrm=iso>. Acesso em: 31 jan. 2013.

MISKOLCI, Richard (2007). Pânicos morais e controle social - reflexões sobre o casamento gay. Cadernos Pagu, n.28, p.101-128, jan./jun. 2007. Disponível em: <http://www.scielo.br/pdf/cpa/n28/06.pdf>. Acesso em: 25 ago. 2013.

MORENO, Antonio (1995). A personagem homossexual no cinema brasileiro. 1995. Dissertação (Mestrado em Artes). Campinas: Universidade Estadual de Campinas.

OROZCO GÓMEZ, G (2005). O telespectador frente à televisão. Uma exploração do processo de recepção televisiva. Comunicare. Vol 5, $\mathrm{n}^{\circ} 1,1^{\circ}$ semestre.

PERET, Luiz Eduardo Neves (2005). Do armário à tela global: a representação social da homossexualidade na telenovela brasileira. Dissertação (Mestrado em Comunicação). Rio de Janeiro: Universidade do Estado do Rio de Janeiro.

RAMOS, Roberto (2012).. Sessenta anos de telenovela no Brasil: Um olhar cultural e crítico. Animus Revista Interamericana de Comunicação Midiática, v.11, n.22, p.394-411. Disponível em: 〈http://cascavel.ufsm.br/revistas/ojs-2.2.2/index.php/animus/article/view/7308/pdf>. Acesso em: 15 out. 2012.

RICH, A. (2010). Heterossexualidade compulsória e existência lésbica. Bagoas, v. 4, n. 5, p. 17-44. Disponível em: <http://www.cchla.ufrn.br/bagoas/v04n05art01_rich.pdf>. Acesso em: 05 mar 2014.

RINCÓN, Omar (2011).. Nuevas narrativas televisivas: relajar, entretener, contar, ciudadanizar, experimentar. Comunicar. Vol. 18, $\mathrm{n}^{\circ} 36$. Disponivel em $<$ http://www.revistacomunicar.com/index.php?contenido=detalles\&numero=36\&articulo=362011-06> Acesso em 15/11/2014. http://dx.doi.org/10.3916/C36-2011-02-04

RONSINI, Veneza V. Mayora (2012). A crença no mérito e a desigualdade: a recepção da telenovela do horário nobre. Porto Alegre: Sulina.

SALIH, Sara (2012). Judith Butler e a Teoria Queer. Belo Horizonte: Autêntica. 
SIMÕES, Júlio Assis \& FRANÇA, Isadora Lins. (2005). "Do gueto ao mercado". In:

GREEN, James Naylor \& TRINDADE, José Ronaldo (eds.). Homossexualismo em São Paulo e outros escritos. São Paulo: Editora da Unesp.

SIMONIS, A (2007). Silencio a gritos: discurso e imágenes del lesbianismo em la literatura. In: Cultura, homosexualid y homofobia. Barcelona: Editorial Laertes. 